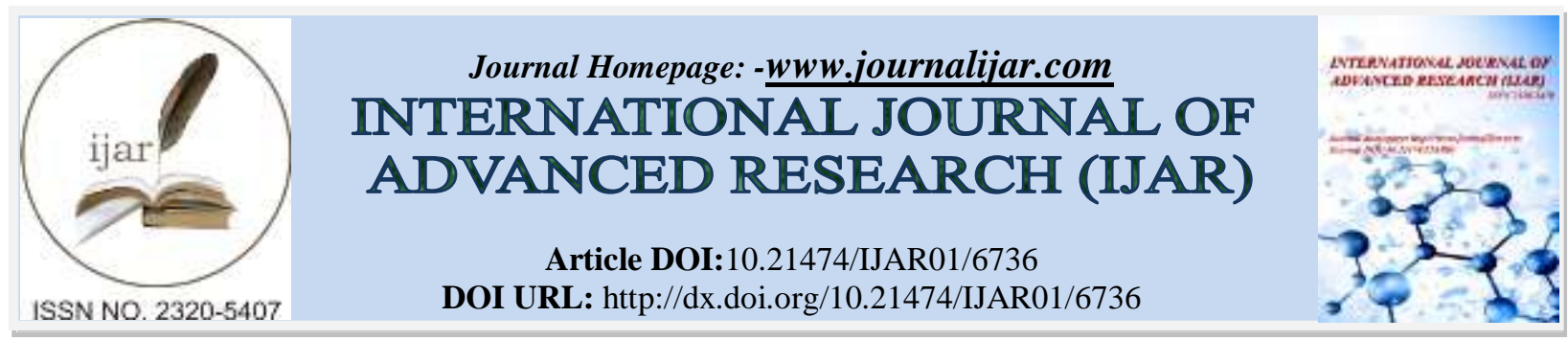

RESEARCH ARTICLE

\title{
DIVERSITY OF ETHNOMEDICINAL PLANTS USED BY MISING TRIBE OF DHEMAJI DISTRICT, ASSAM.
}

\author{
Dulu Rani Chetia and Ajit Kr. Das. \\ Laboratory of Ethnobotany \& Medicinal Plant Conservation, Department of Ecology \& Environmental Science, \\ Assam University, Silchar-788 011.
}

\section{Manuscript Info}

Manuscript History

Received: 13 January 2018

Final Accepted: 15 February 2018

Published: March 2018

\begin{abstract}
An attempt has been made to study of Ethnomedicinal plants used by Mising tribe of Dhemaji district, Assam for the treatment of 48 different diseases like Jaundice, Diabetes, Asthma, Dysentery, Muscular pain, Tonsillitis, Uvulitis, Ringworm, Kidney problem, Small pox, Lactation problem etc. Main aim of the study is to document the indigenous knowledge of the Mising tribe. In this study a total of 142 plant species belonging to 63 families were collected. The prominent family was Euphorbiaceae with 7 species and leaf is used majority of cases with 67 species for the treatment of different diseases. Other different used parts are rhizome, flower, fruit, bark, root, whole plant, seed etc.
\end{abstract}

Copy Right, IJAR, 2018,. All rights reserved.

\section{Introduction:-}

Since ancient time, plants have been an integral part in the existence of human being. Our ancestors dependent upon plants for food, clothing, shelter and many other materials. They derived most of their medicine from plants. It is estimated that a total of $80 \%$ of the population in developing countries and $60 \%$ of the world population depend on traditional medicines mostly plant drugs for their primary health care needs (Baker et al., 1995; Shrestha and Dhillion, 2003). Pei (2001), estimated that traditional healers use around 2500 plant species in the preparation of traditional medicine in India.

According to world health organization, almost $80 \%$ of the rural people rely most exclusively on traditional medicine for their primary health care. Also it is assumed that about $80 \%$ of the 5200 million people of the world live in less developed country. According to Kattamani, et al., (2000), more than $75 \%$ of the world population depends on local health practitioners and traditional medicines for their primary needs.

The studies of the tribal indigenous knowledge of plants constitute an important and preliminary aspect of ethno botanical research (Namsa, et al., 2009). According to Borthakur, 1976, Assam, a state of North-East India is very much rich in flora and fauna and also a homeland of different ethnic groups and cultural entities. Assam comprises $12.8 \%$ of the total tribal population of India with 14 hill tribes (Sajem and Gosai 2006). Dhemaji district is situated in the remote corner of North East India on the north bank of river Brahmaputra. The boundaries of the district are the hilly ranges of Arunachal Pradesh to the North and the East, Lakhimpur district in the West and the river Brahmaputra at in the South. It lies between the $94^{\circ} 12^{\prime} 18^{\prime \prime} \mathrm{E}$ and $95^{\circ} 41^{\prime} 32^{\prime \prime} \mathrm{E}$ longitudes and $27^{\circ} 05^{\prime} 27^{\prime \prime} \mathrm{N}$ and $27^{\circ} 57^{\prime} 16^{\prime \prime} \mathrm{N}$ latitudes. The total geographical area of Dhemaji is $3237 \mathrm{sq} \mathrm{kms}$. The Dhemaji district was originally inhabited by various indigenous tribes includes Mising, Sonowal Kachari, Bodo Kachari, Deori and Laloong. 
Mising is the major dominated tribe found in Dhemaji district. According to 2011 census there are 325560 (47.45\%) population of schedule tribe followed by $44225(6.45 \%)$ population of schedule caste found in Dhemaji district.

\section{Mising tribe:-}

The Mishing (Miris) belong to the family of the aboriginal tribes of the north eastern region of India and settle in the plains of Assam. They chiefly inhabiting the districts of Lakhimpur, Dhemaji, Dibrugarh, Tinsukia, Sibsagar, Jorhat, Golaghat and Sonitpur. Next to Bodos, the Mising are the largest tribal group in North East India. Generally Mising live in Chang ghar which is situated on the bank of river. They mainly depends on agriculture.

Important festivals of the Mising tribe are Ali-ai-ligang and Porag. Both are associated with cultivation cycle. Ali-ailigang is celebrated during the month of February and it is the beginning of their agriculture cycle. Porag was celebrated earlier in the months of August or September and it is the post-harvest festival. The dances of Mising tribe is called Maksong or Soman and it bear great similarity with the Bihu dance of Assam. Local instruments used by Mishing tribe are Drum, Clapping Metal bells and Bansuri.

According to Census of India conducted in 2001, the population of Mishing in Assam is counted to 5,87,310; of which 2,99,790 Male and 2,87,520 female.

\section{Methodology:-}

A survey was conducted during September 2016 - December 2017 to collect information on the medicinal plants used by Mising tribe of Dhemaji district of Assam. Different villages of the district were visited to collect information as well as plant species with their reproductive parts. The informations were collected from the Headman, both women and man healers and common people. Herbarium of the collected specimens were prepared based on methodology laid down by Jain and Rao, 1977. For further reference, the herbarium specimens have been deposited in the Department of Ecology and Environmental Science. The identification of the plants was done with the help of the floristic literature like, Flora of India (Sharma et al., 1993), Flora of Assam (Kanjilal et al., 19341940; Bor, 1940), Medicinal plants of Southern Assam (Das, et al., 2010) etc.

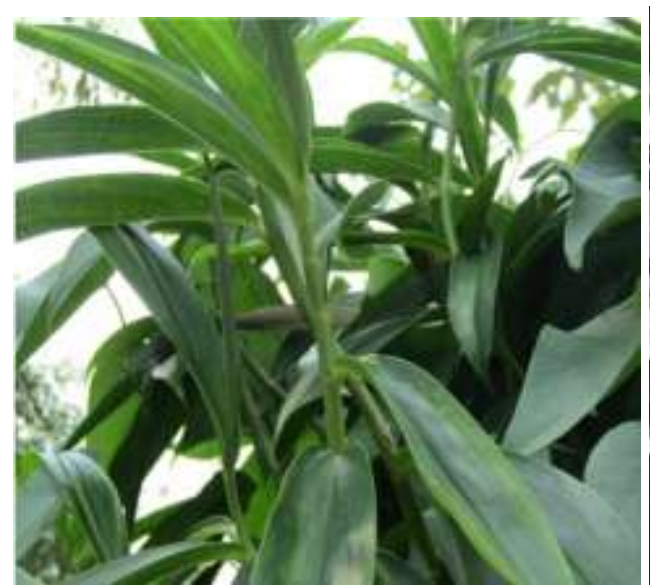

Costus speciosus (J.Koenig) Sm.

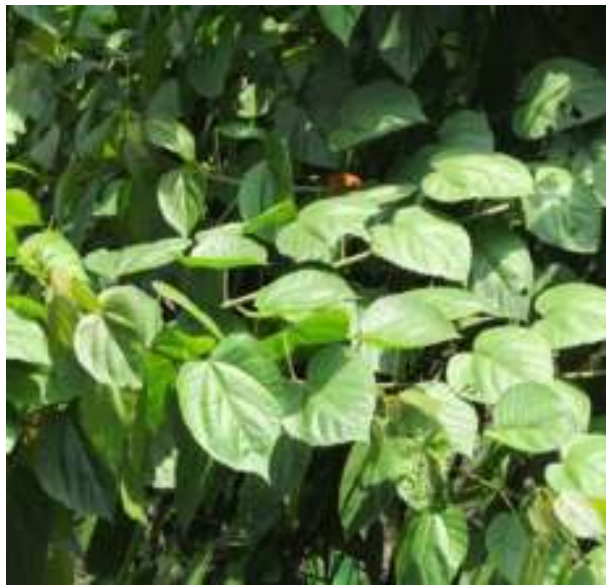

Croton caudatus Geiseler 


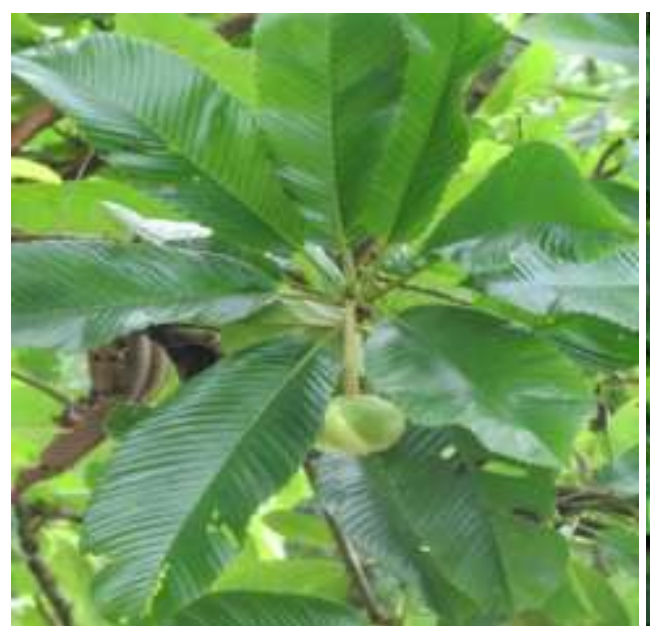

Dillenia indica L.

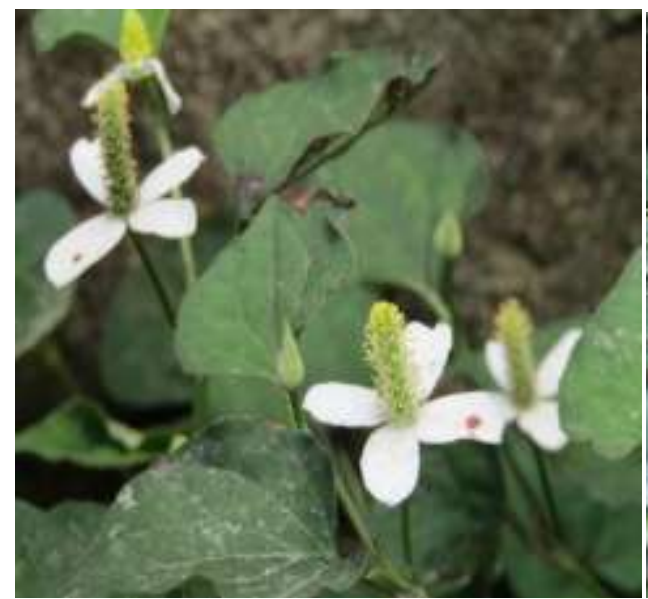

Houttuynia cordata Thunb.

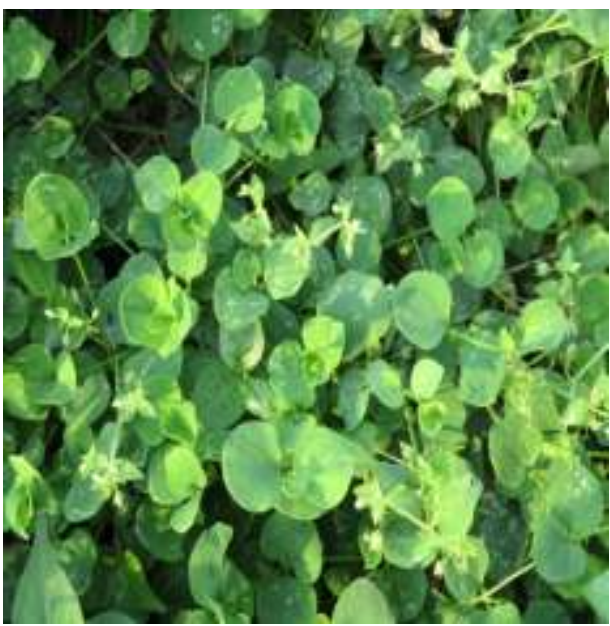

Drymaria cordata Willd. ex Schult.

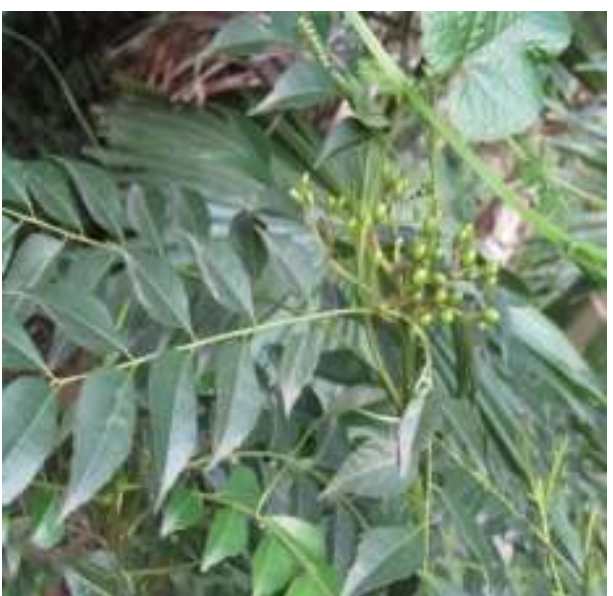

Murraya koenigii (L.) Spreng.

Table 1:- Ethnomedicinal plant species used by Mising tribe.

\begin{tabular}{|c|c|c|c|c|}
\hline Scientific name & $\begin{array}{l}\text { Common } \\
\text { name }\end{array}$ & Family & Parts used & Medicinal uses \\
\hline $\begin{array}{l}\text { Abelmoschus manihot } \\
\text { (L.) Medic. }\end{array}$ & Usipak & Malvaceae & Leaves & $\begin{array}{l}\text { Leaves are mainly used for } \\
\text { Carbuncle disease. }\end{array}$ \\
\hline Abrus precatorius $\mathrm{L}$. & Latumoni & Leguminaceae & Seed & $\begin{array}{l}\text { Seed extract is used to cure } \\
\text { pneumonia. }\end{array}$ \\
\hline Acacia nilotica $\mathrm{L}$. & Tarua kadam & Fabaceae & Bark & $\begin{array}{l}\text { Extract of bark is used to cure } \\
\text { tonsillitis. }\end{array}$ \\
\hline $\begin{array}{l}\text { Achyranthes aspera } \\
\text { L. }\end{array}$ & Bioni hakuta & Amaranthaceae & Leaves & $\begin{array}{l}\text { Leaf decoction is used in the } \\
\text { treatment of cough. }\end{array}$ \\
\hline $\begin{array}{l}\text { Acmella paniculata } \\
\text { (DC.) R.K.Jansen }\end{array}$ & Huhoni ban & Asteraceae & $\begin{array}{l}\text { Flower and } \\
\text { Leaves }\end{array}$ & $\begin{array}{l}\text { Flower is used to cure the pain of } \\
\text { tooth and mouth ulcer. Leaves are } \\
\text { eaten as vegetable. }\end{array}$ \\
\hline Acorus calamus L. & Bosh & Araceae & Rhizome & $\begin{array}{l}\text { Rhizome is mainly used for } \\
\text { dyspepsia. It is also used to cure } \\
\text { abdominal pain during } \\
\text { menstruation period of woman. }\end{array}$ \\
\hline $\begin{array}{l}\text { Adhatoda } \\
\text { vasica } \text { Nees }\end{array}$ & Bahak tita & Acanthaceae & Leaves & $\begin{array}{l}\text { Leaf extract is used to cure } \\
\text { jaundice. }\end{array}$ \\
\hline Aegle marmelos (L.) & $\mathrm{Bel}$ & Rutaceae & Fruit & Fruit is used in diarrhea and \\
\hline
\end{tabular}




\begin{tabular}{|c|c|c|c|c|}
\hline Correa & & & & dysentery. Ripe fruit is edible. \\
\hline $\begin{array}{l}\text { Ageratum conyzoides } \\
\text { L. }\end{array}$ & Gendhela ban & Asteraceae & Leaves & $\begin{array}{l}\text { Leaf juice is applied in fresh cuts } \\
\text { and wounds to stop bleeding. }\end{array}$ \\
\hline Allium sativum $\mathrm{L}$. & Naharu & Liliaceae & Seeds & $\begin{array}{l}\text { Seeds are used to cure high blood } \\
\text { pressure. Seed is eaten at the time } \\
\text { of indigestion. }\end{array}$ \\
\hline $\begin{array}{l}\text { Aloe } \quad \text { barbadensis } \\
\text { Mill. }\end{array}$ & Salkuori & Liliaceae & Leaves & $\begin{array}{l}\text { Paste of leaves are used to cure } \\
\text { skin burn and also used externally } \\
\text { for hair growth. Leaf juice is used } \\
\text { to cure stomach ache. }\end{array}$ \\
\hline $\begin{array}{l}\text { Alpinia nigra } \\
\text { (Gaertn.) B.L.Burtt }\end{array}$ & Tora & Zingiberaceae & Rhizome & $\begin{array}{l}\text { Rhizome is used to cure bronchitis } \\
\text { and rheumatism. }\end{array}$ \\
\hline $\begin{array}{l}\text { Alstonia scholaris (L.) } \\
\text { R.Br. }\end{array}$ & Chationa & Apocynaceae & Bark & $\begin{array}{l}\text { Bark is used during childbirth to } \\
\text { increase lactation of milk and } \\
\text { malaria. }\end{array}$ \\
\hline $\begin{array}{l}\text { Alternanthera sessilis } \\
\text { (L.) DC. }\end{array}$ & Matikanduri & Amaranthaceae & Leaves & $\begin{array}{l}\text { The shoot part is eaten as } \\
\text { vegetables and also used against } \\
\text { dysentery. }\end{array}$ \\
\hline $\begin{array}{l}\text { Amaranthus spinosus } \\
\text { L. }\end{array}$ & Hati-khutura & Amaranthaceae & $\begin{array}{ll}\text { Root } & \text { and } \\
\text { Leaves }\end{array}$ & $\begin{array}{l}\text { Root juice is used to cure jaundice. } \\
\text { Leaves are eaten as vegetables. }\end{array}$ \\
\hline $\begin{array}{l}\text { Amorphophallus } \\
\text { paeoniifolius } \\
\text { (Dennst.) Nicolson }\end{array}$ & Ol-kachu & Araceae & Root & $\begin{array}{l}\text { Dried root is used to cure piles. } \\
\text { Tender shoot is eaten as } \\
\text { vegetables. }\end{array}$ \\
\hline Amaranthus viridis L. & Khutura & Amaranthaceae & Whole plant & $\begin{array}{l}\text { Whole plant is used to cure high } \\
\text { fever and also eaten as vegetables. }\end{array}$ \\
\hline $\begin{array}{l}\text { Andrographis } \\
\text { paniculata Nees }\end{array}$ & Sirata & Acanthaceae & Leaves & $\begin{array}{l}\text { Leaves are eaten against fever, and } \\
\text { gastric. Leaf paste applied against } \\
\text { boil. }\end{array}$ \\
\hline $\begin{array}{l}\text { Ananas comosus (L.) } \\
\text { Merr. }\end{array}$ & Mati-kothal & Bromoliaceae & $\begin{array}{l}\text { Leaves and } \\
\text { Fruit }\end{array}$ & $\begin{array}{l}\text { The tender leaves mainly used for } \\
\text { urine problem. Ripe fruit is edible. }\end{array}$ \\
\hline $\begin{array}{l}\text { Artocarpus } \\
\text { heterophyllus Lam. }\end{array}$ & Kothal & Moraceae & $\begin{array}{l}\text { Seed and } \\
\text { Fruit }\end{array}$ & $\begin{array}{l}\text { Young fruit and seeds are used as } \\
\text { vegetable. Ripe fruits are edible. }\end{array}$ \\
\hline $\begin{array}{l}\text { Averrhoa carambola } \\
\text { L. }\end{array}$ & Kordoi & Oxalidaceae & $\begin{array}{l}\text { Fruit and } \\
\text { Leaves }\end{array}$ & $\begin{array}{l}\text { Fruit juice is used to cure jaundice. } \\
\text { Fruit is edible. Leaf juice is used } \\
\text { to cure ringworm. }\end{array}$ \\
\hline $\begin{array}{l}\text { Azadirachta indica A. } \\
\text { Juss }\end{array}$ & Mahaneem & Meliaceae & Leaves & $\begin{array}{l}\text { Leaf paste is applied to cure skin } \\
\text { disease and small pox. Leaves are } \\
\text { used against pneumonia. }\end{array}$ \\
\hline $\begin{array}{l}\text { Baccaurea sapida } \\
\text { Bedd. }\end{array}$ & Leteku & Euphorbiaceae & Fruit & $\begin{array}{l}\text { Ripe fruit is edible and also used } \\
\text { against diabetes. }\end{array}$ \\
\hline $\begin{array}{l}\text { Bacopa monnieri (L.) } \\
\text { Pennell }\end{array}$ & Brahmi & Scrophulariaceae & Whole plant & $\begin{array}{l}\text { Whole plant is very effective in } \\
\text { memory and also reduce high } \\
\text { blood pressure. }\end{array}$ \\
\hline $\begin{array}{l}\text { Bambusa balcooa } \\
\text { Roxb. }\end{array}$ & Valuka bah & Poaceae & Tender shoot & $\begin{array}{l}\text { Tender shoot is used to cure high } \\
\text { blood pressure and asthma. }\end{array}$ \\
\hline $\begin{array}{l}\text { Bryophyllum } \\
\text { calycinum Salisb. }\end{array}$ & Dupartenga & Crassulaceae & Leaves & $\begin{array}{l}\text { Fresh leaf juice is used for } \\
\text { stomach pain and urine problem. }\end{array}$ \\
\hline $\begin{array}{l}\text { Caesalpinia bonduc } \\
\text { (L.) Roxb. }\end{array}$ & Letaguti & Caesalpiniaceae & $\begin{array}{l}\text { Leaves and } \\
\text { Seed }\end{array}$ & $\begin{array}{l}\text { Leaves are used to cure illness. } \\
\text { Seeds are used in pneumonia. }\end{array}$ \\
\hline Calamus rotang $\mathrm{L}$. & Bet & Arecaceae & $\begin{array}{l}\text { Shoot and } \\
\text { Seed }\end{array}$ & $\begin{array}{l}\text { Tender shoot is eaten as } \\
\text { vegetables. Fruit is edible. }\end{array}$ \\
\hline $\begin{array}{l}\text { Calotropis gigantea } \\
\text { (L) W. T. Aiton }\end{array}$ & Akon & Asclepiadaceae & Leaves & $\begin{array}{l}\text { Leaf paste is applied against body } \\
\text { pain and leaf juice is used to cure } \\
\text { piles. }\end{array}$ \\
\hline
\end{tabular}




\begin{tabular}{|c|c|c|c|c|}
\hline $\begin{array}{l}\text { Canarium strictum } \\
\text { Roxb. }\end{array}$ & Dhuna & Burseraceae & Resin & Resins are used in snake bite. \\
\hline Cannabis sativa $\mathrm{L}$. & Bhang & Cannabaceae & Leaves & Leaves are used for cough. \\
\hline Capsicum anпиит $\mathrm{L}$. & Jolokia & Solanaceae & $\begin{array}{l}\text { Root and } \\
\text { Leaves }\end{array}$ & $\begin{array}{l}\text { Root paste is used against } \\
\text { dysentery. Leaf paste are applied } \\
\text { to cure insect bite. }\end{array}$ \\
\hline $\begin{array}{l}\text { Capsicum frutescens } \\
\mathrm{L} .\end{array}$ & Kon-jolokia & Solanaceae & Fruit & $\begin{array}{l}\text { Ripe fruit paste is used to cure } \\
\text { tonsillitis. }\end{array}$ \\
\hline Carica papaya $\mathrm{L}$. & Amita & Caricaceae & $\begin{array}{l}\text { Leaves and } \\
\text { Fruit }\end{array}$ & $\begin{array}{l}\text { Leaf paste is used to cure fever } \\
\text { and ringworm. Fruit is used during } \\
\text { childbirth to increase lactation of } \\
\text { milk. }\end{array}$ \\
\hline $\begin{array}{l}\text { Cascabela thevetia } \\
\text { (L.) Lippold }\end{array}$ & Karabiful & Apocynaceae & $\begin{array}{l}\text { Stem and } \\
\text { Bark }\end{array}$ & $\begin{array}{l}\text { Bark is used to cure Malaria and } \\
\text { latex of stem is used against boils. }\end{array}$ \\
\hline Cassia alata $\mathrm{L}$. & Khorgos & Caesalpiniaceae & Leaves & $\begin{array}{l}\text { Leaves are crushed and applied } \\
\text { locally for ringworm disease. }\end{array}$ \\
\hline Cassia occidentalis L. & Medelua & Caesalpiniaceae & Leaves & $\begin{array}{l}\text { Leaf paste is applied against } \\
\text { ringworm. }\end{array}$ \\
\hline $\begin{array}{l}\text { Catharanthus roseus } \\
\text { (L.) }\end{array}$ & Nayantara & Apocynaceae & $\begin{array}{l}\text { Flower and } \\
\text { Leaves }\end{array}$ & $\begin{array}{l}\text { Flower is used for treatment of } \\
\text { Cancer. Leaves are used to cure } \\
\text { diabetes. }\end{array}$ \\
\hline Centella asiatica Urb. & Bor-manimuni & Apiaceae & Leaves & $\begin{array}{l}\text { Paste of green leaves are used for } \\
\text { stomach ache and small pox. It is } \\
\text { also used for pneumonia and skin } \\
\text { disease. }\end{array}$ \\
\hline $\begin{array}{l}\text { Chenopodium album } \\
\text { L. }\end{array}$ & Jilmilsak & Chenopodiaceae & $\begin{array}{l}\text { Leaves and } \\
\text { Tender shoot }\end{array}$ & $\begin{array}{l}\text { It is mainly used for stomach pain, } \\
\text { leaves are also used as vegetable } \\
\text { by Mising tribe. }\end{array}$ \\
\hline $\begin{array}{l}\text { Chromolina odorata } \\
\text { (L.) R.M.King \& } \\
\text { H.Rob. }\end{array}$ & $\begin{array}{l}\text { Bagh-dhokal } \\
\text { bembonamkil }\end{array}$ & Asteraceae & Leaves & $\begin{array}{l}\text { Leaf paste is used to cure cut and } \\
\text { wounds. }\end{array}$ \\
\hline $\begin{array}{l}\text { Cinnamomum tamala } \\
\text { T.Nees \& Eberm. }\end{array}$ & Tejpat & Lauraceae & Leaves & It is mainly used for sleepness. \\
\hline $\begin{array}{l}\text { Cissampelos } \\
\text { sympodialis Eichl. }\end{array}$ & Thupuki-lota & Menispermaceae & Leaves & $\begin{array}{l}\text { Leaves decoction is used to cure } \\
\text { fever. }\end{array}$ \\
\hline $\begin{array}{l}\text { Cissus } \\
\text { quadrangularis } \mathrm{L} .\end{array}$ & Harjuralota & Vitaceae & Stem & $\begin{array}{l}\text { The paste of stem is used to cure } \\
\text { bone fracture. }\end{array}$ \\
\hline $\begin{array}{l}\text { Cinnamomum verum } \\
\text { J.Presl }\end{array}$ & Dalcheni & Lauraceae & Bark & $\begin{array}{l}\text { Bark is mixed with honey to cure } \\
\text { cough. }\end{array}$ \\
\hline $\begin{array}{l}\text { Citrus aurantifolia } \\
\text { Linn }\end{array}$ & Kaji-Nemu & Rutaceae & Fruit & $\begin{array}{l}\text { Fruit is used to cure stomach ache } \\
\text { and dysentery. }\end{array}$ \\
\hline Citrus medica L. & Golneти & Rutaceae & $\begin{array}{l}\text { Fruit and } \\
\text { Leaves }\end{array}$ & $\begin{array}{l}\text { Fruit juice is used to cure diarrhea } \\
\text { and leaves are used to cure } \\
\text { pneumonia. }\end{array}$ \\
\hline $\begin{array}{l}\text { Clerodendrum } \\
\text { serratum Spreng. }\end{array}$ & Nangalbhanga & Verbenaceae & $\begin{array}{l}\text { Leaves and } \\
\text { Root }\end{array}$ & $\begin{array}{l}\text { Root decoction is given against } \\
\text { dysentery. Crushed leaves are } \\
\text { applied to cuts and wounds. }\end{array}$ \\
\hline $\begin{array}{l}\text { Clerodendrum } \\
\text { colebrookianum } \\
\text { Walp. }\end{array}$ & Nephaphu & Verbenaceae & Leaves & $\begin{array}{l}\text { Leaves are used to cure high blood } \\
\text { pressure and also used as } \\
\text { vegetable. }\end{array}$ \\
\hline $\begin{array}{l}\text { Coccinia grandis }(\mathrm{L} .) \\
\text { Voigt }\end{array}$ & Kunduli & Cucurbitaceae & Fruit & $\begin{array}{l}\text { Fruits are eaten as vegetables to } \\
\text { cure diabetes. }\end{array}$ \\
\hline Coix lacryma-jobi L. & Kawari-moni & Poaceae & Root & Root juice is used to cure \\
\hline
\end{tabular}




\begin{tabular}{|c|c|c|c|c|}
\hline & & & Fruit & $\begin{array}{l}\text { menstruation trouble. Fruit is used } \\
\text { in the treatment of diarrhea. }\end{array}$ \\
\hline $\begin{array}{l}\text { Colocasia esculenta } \\
\text { (L.) Schott. }\end{array}$ & Kochu & Araceae & $\begin{array}{l}\text { Tender } \\
\text { leaves and } \\
\text { Stem }\end{array}$ & $\begin{array}{l}\text { It is eaten as vegetables. Stem } \\
\text { paste is applied against cut and } \\
\text { wounds. }\end{array}$ \\
\hline $\begin{array}{l}\text { Corchorus capsularis } \\
\text { L. }\end{array}$ & Morapat & Malvaceae & Leaves & $\begin{array}{l}\text { Tender leaves are used against } \\
\text { dysentery and also eaten as } \\
\text { vegetables. }\end{array}$ \\
\hline $\begin{array}{l}\text { Costus } \quad \text { speciosus } \\
\text { (J.Koenig) Sm. }\end{array}$ & Jamlakhuti & Costaceae & Whole plant & $\begin{array}{l}\text { Leaves are used to cure gastric, the } \\
\text { plant is used for fever and urinal } \\
\text { disorder. Roots are used to cure } \\
\text { jaundice. }\end{array}$ \\
\hline $\begin{array}{l}\text { Crataeva magna } \\
\text { (Lour.) DC. }\end{array}$ & Barun & Capparidaceae & Bark & $\begin{array}{l}\text { Bark is used for liver problem and } \\
\text { urination trouble. }\end{array}$ \\
\hline $\begin{array}{ll}\text { Croton } & \text { caudatus } \\
\text { Geiseler }\end{array}$ & Hati mahudi & Euphorbiaceae & $\begin{array}{l}\text { Root and } \\
\text { Latex }\end{array}$ & $\begin{array}{l}\text { Root is used to cure pneumonia. } \\
\text { Latex is used to cure enlargement } \\
\text { of Uvula. }\end{array}$ \\
\hline Croton tiglium $\mathrm{L}$. & Konibih & Euphorbiaceae & Tender shoot & $\begin{array}{l}\text { Leaf paste applied to cure skin } \\
\text { itching and shoot are used to cure } \\
\text { diarrhea. }\end{array}$ \\
\hline $\begin{array}{l}\text { Curcuma caesia } \\
\text { Roxb. }\end{array}$ & Kola haladhi & Zingiberaceae & Rhizome & $\begin{array}{l}\text { It is used to cure kidney stone and } \\
\text { cough. }\end{array}$ \\
\hline Curcuma longa $\mathrm{L}$. & Haldhi & Zingiberaceae & Rhizome & $\begin{array}{l}\text { The juice of rhizome mixed with } \\
\text { honey to cure cough and } \\
\text { bronchitis. Rhizome paste is } \\
\text { applied against abdominal pain. }\end{array}$ \\
\hline Cuscuta reflexa Roxb. & Akashi lota & Convolvulaceae & Leaves & $\begin{array}{l}\text { Leaf juice is used to cure fever. } \\
\text { Leaves are used to get relief from } \\
\text { dysentery and also used to cure } \\
\text { high blood pressure. }\end{array}$ \\
\hline $\begin{array}{l}\text { Cynodon dactylon } \\
\text { (L.) Pers. }\end{array}$ & Dubori bon & Poaceae & Whole plant & $\begin{array}{l}\text { Paste of the plant is applied to cuts } \\
\text { and wounds to stop bleeding. Leaf } \\
\text { juice is taken orally against } \\
\text { diarrhea. }\end{array}$ \\
\hline Cyperus rotundus L. & Keya ban & Cyperaceae & Whole plant & $\begin{array}{l}\text { Crushed plant with honey is used } \\
\text { in stomach problem. }\end{array}$ \\
\hline $\begin{array}{l}\text { Dactyloctenium } \\
\text { aegyptium (L.) Willd. }\end{array}$ & Bobosa bon & Poaceae & Culm & $\begin{array}{l}\text { Culm decoction is used against } \\
\text { asthma. }\end{array}$ \\
\hline Datura stramonium L. & Dhatura & Solanaceae & Leaves & $\begin{array}{l}\text { Leaves are used externally to relief } \\
\text { from muscular pain. }\end{array}$ \\
\hline Dillenia indica L. & Outenga & Dilleniaceae & $\begin{array}{l}\text { Bracts and } \\
\text { Fruit }\end{array}$ & $\begin{array}{l}\text { The juice of bracts is used to cure } \\
\text { in fevers, diarrhea, dysentery. Fruit } \\
\text { used as vegetable. }\end{array}$ \\
\hline $\begin{array}{l}\text { Drymaria cordata } \\
\text { Willd. ex Schult. }\end{array}$ & Laijabori & Caryophyllaceae & Leaves & $\begin{array}{l}\text { Leaf paste is used in the treatment } \\
\text { of Jaundice. Crushed leaves used } \\
\text { as medicine for sinus problem. } \\
\text { Leaves are used to cure pain at the } \\
\text { time of menstruation. }\end{array}$ \\
\hline $\begin{array}{l}\text { Duchesnea indica } \\
\text { (Andrews) Focke. }\end{array}$ & Goru khis & Rosaceae & Fruit & $\begin{array}{l}\text { Fruit paste is used to cure boil. } \\
\text { Leaf decoction is used against skin } \\
\text { itching. }\end{array}$ \\
\hline $\begin{array}{l}\text { Emblica officinalis } \\
\text { Gaertn. }\end{array}$ & Amlokhi & Euphorbiaceae & Fruit & $\begin{array}{l}\text { Fruit juice is used to cure jaundice } \\
\text { and dysentery. }\end{array}$ \\
\hline Eryngium foetidum L. & Man dhania & Apiaceae & Leaves & Leaf juice is used for stomach \\
\hline
\end{tabular}




\begin{tabular}{|c|c|c|c|c|}
\hline & & & & ache and also eaten as vegetable. \\
\hline $\begin{array}{l}\text { Erythrina } \quad \text { stricta } \\
\text { Roxb. }\end{array}$ & $\begin{array}{l}\text { Rangamadarl } \\
\text { Tagat }\end{array}$ & Fabaceae & Bark & It is used to cure piles disease. \\
\hline Euphorbia hirta L. & Gakhirati bon & Euphorbiaceae & Whole plant & $\begin{array}{l}\text { Plant is used to cure lactation } \\
\text { problem and also cure asthma } \\
\text { problem. }\end{array}$ \\
\hline $\begin{array}{l}\text { Garcinia lanceifolia } \\
\text { Roxb. }\end{array}$ & Rupohithekera & Clusiaceae & Fruit & $\begin{array}{l}\text { Fruit is used to cure diarrhea. Fruit } \\
\text { is edible. }\end{array}$ \\
\hline Garcinia cowa Roxb. & Kujithekera & Clusiaceae & Fruit & $\begin{array}{l}\text { The pieces of dried fruit is mixed } \\
\text { with water and given to cure } \\
\text { dysentery and diarrhea. }\end{array}$ \\
\hline $\begin{array}{l}\text { Garcinia pedunculata } \\
\text { Roxb. }\end{array}$ & Borthekera & Clusiaceae & Fruit & $\begin{array}{l}\text { It is used to cure dysentery and } \\
\text { diarrhea. }\end{array}$ \\
\hline $\begin{array}{l}\text { Hedyotis corymbosa } \\
\text { (L.) Lam. }\end{array}$ & Bonjaluk & Rubiaceae & Whole plant & $\begin{array}{l}\text { Leaves are used to cure small pox. } \\
\text { Whole plant is used for treatment } \\
\text { of cough and pneumonia. Leaves } \\
\text { are used to cure pain at the time of } \\
\text { menstruation. }\end{array}$ \\
\hline $\begin{array}{l}\text { Hibiscus rosa-sinensis } \\
\text { L. }\end{array}$ & Joba & Malvaceae & Flower & $\begin{array}{l}\text { Flowers paste is applied on } \\
\text { wounds and also used against } \\
\text { dandruff. }\end{array}$ \\
\hline Hibiscus sabdariffa $\mathrm{L}$. & Tengamara & Malvaceae & Tender shoot & $\begin{array}{l}\text { Juice of tender shoot is used to } \\
\text { cure dysentery. Also used as } \\
\text { vegetables. }\end{array}$ \\
\hline $\begin{array}{l}\text { Houttuynia cordata } \\
\text { Thunb. }\end{array}$ & Mochundori & Saururaceae & Leaves & $\begin{array}{l}\text { Leaves are used to cure Dysentery } \\
\text { and urine problem. It is also eaten } \\
\text { as vegetable. }\end{array}$ \\
\hline $\begin{array}{l}\text { Hydrocotyle } \\
\text { sibthorpioides Lam. }\end{array}$ & Harumanimuni & Apiaceae & Leaves & $\begin{array}{l}\text { Juice of the leaves is used to cure } \\
\text { dysentery. }\end{array}$ \\
\hline Jatropha curcas L. & Bangali era & Euphorbiaceae & $\begin{array}{l}\text { Leaves and } \\
\text { Bark }\end{array}$ & $\begin{array}{l}\text { Leaves are used to cure headache, } \\
\text { bark is used for vomiting and body } \\
\text { pain. }\end{array}$ \\
\hline $\begin{array}{ll}\text { Justicia } & \text { gendarussa } \\
\text { Burm.f. } & \end{array}$ & ------------- & Acanthaceae & Leaves & $\begin{array}{l}\text { It is useful for rheumatism and } \\
\text { headache. }\end{array}$ \\
\hline $\begin{array}{l}\text { Kaempferia galanga } \\
\text { L. }\end{array}$ & Gathion & Zingiberaceae & Rhizome & $\begin{array}{l}\text { The juice of rhizome is used to } \\
\text { cure cough and cold. }\end{array}$ \\
\hline $\begin{array}{l}\text { Lagenaria siceraria } \\
\text { Standl. }\end{array}$ & Jatilao & Cucurbitaceae & Tender shoot & $\begin{array}{l}\text { The juice of tender shoot is used to } \\
\text { cure burn injury. }\end{array}$ \\
\hline Lawsonia inermis $\mathrm{L}$. & Jetuka & Lythraceae & Leaves & $\begin{array}{l}\text { Leaf paste is applied to cure skin } \\
\text { problem and dandruff. }\end{array}$ \\
\hline Leucas aspera Link & Durun & Lamiaceae & Leaves & $\begin{array}{l}\text { Leaves juice is applied in sinus, } \\
\text { cold and cough. Leaves are also } \\
\text { used to cure small pox. }\end{array}$ \\
\hline Mangifera indica $\mathrm{L}$. & Aam & Anacardiaceae & Fruit & $\begin{array}{l}\text { Both ripe and unripe fruit are } \\
\text { eaten. Fresh fruit is used to cure } \\
\text { piles. }\end{array}$ \\
\hline Melia azedarach L. & Ghuraneem & Meliaceae & Leaves & $\begin{array}{l}\text { Leaf paste is applied externally for } \\
\text { skin diseases. }\end{array}$ \\
\hline Mentha arvensis L. & Podina & Lamiaceae & Leaves & $\begin{array}{l}\text { Green leaves are used to cure urine } \\
\text { disease and digestive disorder. } \\
\text { Also used as vegetable. }\end{array}$ \\
\hline $\begin{array}{l}\text { Mikania micrantha } \\
\text { Kunth }\end{array}$ & Riphujilata & Asteraceae & Leaves & $\begin{array}{l}\text { Leaves are used to cure dysentery } \\
\text { and paste of leaves used against } \\
\text { high blood pressure. }\end{array}$ \\
\hline
\end{tabular}




\begin{tabular}{|c|c|c|c|c|}
\hline Mimosa pudica $\mathrm{L}$. & Nilajiban & Mimosaceae & Whole plant & $\begin{array}{l}\text { Decoction of the whole plant is } \\
\text { taken in kidney trouble. Root paste } \\
\text { is used to cure fever. }\end{array}$ \\
\hline Mimusops elengi L. & Bokul & Sapotaceae & $\begin{array}{l}\text { Stem and } \\
\text { Bark }\end{array}$ & $\begin{array}{l}\text { Stem, bark is useful in tooth ache. } \\
\text { Bark decoction is used to cure } \\
\text { fever. }\end{array}$ \\
\hline Mirabilis jalapa L. & Gadhuligupal & Nyctaginaceae & Root & $\begin{array}{l}\text { Extract of root is used to cure } \\
\text { piles. }\end{array}$ \\
\hline $\begin{array}{l}\text { Momordica } \\
\text { charantia L. }\end{array}$ & Karela & Cucubitaceae & Fruit & $\begin{array}{l}\text { Fruit juice is used to cure Diabetes } \\
\text { and also used as vegetable. }\end{array}$ \\
\hline $\begin{array}{ll}\text { Moringa } & \text { oleifera } \\
\text { Lam. } & \end{array}$ & Sojina & Moringaceae & Seed & $\begin{array}{l}\text { Seed paste is used externally on } \\
\text { the effected part of the body for } \\
\text { rheumatic pain and also used as } \\
\text { vegetable. }\end{array}$ \\
\hline Morus australis Poir. & Nunigos & Moraceae & Fruit & $\begin{array}{l}\text { Fruit paste is eaten for } \\
\text { Constipation. }\end{array}$ \\
\hline $\begin{array}{l}\text { Murraya koenigii (L.) } \\
\text { Spreng }\end{array}$ & Narasingha & Rutaceae & Leaves & $\begin{array}{l}\text { The juice of the leave is used for } \\
\text { the treatment of dysentery and } \\
\text { pneumonia. Leaf paste is used } \\
\text { against dandruff. }\end{array}$ \\
\hline Musa sapientum L. & Bhimkol & Musaceae & $\begin{array}{l}\text { Inflorescence } \\
\text { and Fruit }\end{array}$ & $\begin{array}{l}\text { Inflorescence is used to cure low } \\
\text { blood pressure. Ripe fruit is edible. }\end{array}$ \\
\hline Musa paradisiaca $\mathrm{L}$. & Jahajikol & Musaceae & $\begin{array}{l}\text { Bark and } \\
\text { Fruit }\end{array}$ & $\begin{array}{l}\text { Bark is used to cure diabetes. Ripe } \\
\text { fruit is edible. }\end{array}$ \\
\hline $\begin{array}{l}\text { Mussaenda } \\
\text { roxburghii Hook.f. }\end{array}$ & Sraswati pat & Rubiaceae & Leaves & $\begin{array}{l}\text { Leaf paste is used against snake } \\
\text { bite. }\end{array}$ \\
\hline $\begin{array}{l}\text { Nyctanthes arbor- } \\
\text { tristis L. }\end{array}$ & Sewali & Oleaceae & Leaves & $\begin{array}{l}\text { Leaf juice is used for cough and } \\
\text { vomiting. }\end{array}$ \\
\hline Ocimum basilicum $\mathrm{L}$. & Bor-tulshi & Lamiaceae & Leaves & $\begin{array}{l}\text { Leaf juice is used to cure fever, } \\
\text { cough and Malaria. }\end{array}$ \\
\hline Ocimum sanctum $\mathrm{L}$. & Tulshi & Lamiaceae & Leaves & $\begin{array}{l}\text { Leaf juice is used for cough and } \\
\text { asthma. }\end{array}$ \\
\hline Oxalis corniculata $\mathrm{L}$. & Tengeshi tenga & 0xalidaceae & Leaves & $\begin{array}{l}\text { Leaves are used to apply over the } \\
\text { infected eczema portion. It is also } \\
\text { eaten as vegetable. Leaf juice is } \\
\text { used to cure fever and dysentery. }\end{array}$ \\
\hline $\begin{array}{l}\text { Paederia scandens } \\
\text { (Lour.) Merr. }\end{array}$ & Bhedailata & Rubiaceae & Leaves & $\begin{array}{l}\text { Paste of leaves juice is used for } \\
\text { gastric and also anti dysenteric. } \\
\text { Also eaten as vegetable. }\end{array}$ \\
\hline $\begin{array}{l}\text { Phlogacanthus } \\
\text { thyrsiflorus Nees. }\end{array}$ & Titaful & Acanthaceae & Leaves & $\begin{array}{l}\text { Leaf juice is used for fever. Leaves } \\
\text { are used to cure cough. }\end{array}$ \\
\hline Physalis minima L. & Futkola & Solanaceae & Whole plant & $\begin{array}{l}\text { Whole plant is used to cure } \\
\text { headache. }\end{array}$ \\
\hline Piper betle $\mathrm{L}$. & Pan & Piperaceae & Leaves & $\begin{array}{l}\text { Leaves extract is mixed with } \\
\text { honey and given to cure cough. }\end{array}$ \\
\hline Piper longum L. & Pipoli & Piperaceae & Leaves & Leaves are used to cure cough. \\
\hline Piper nigrum Wall. & Jaluk & Piperaceae & Seed & $\begin{array}{l}\text { Seeds mixed with misri to get } \\
\text { relief from cough. It is used to } \\
\text { cure tonsillitis. }\end{array}$ \\
\hline $\begin{array}{l}\text { Pogostemon } \\
\text { benghalensis Kuntze }\end{array}$ & Hukloti & Lamiaceae & Leaves & $\begin{array}{l}\text { Leaves are used to cure stomach } \\
\text { pain. }\end{array}$ \\
\hline $\begin{array}{l}\text { Polygonum chinense } \\
\text { L. }\end{array}$ & Madhu-huleng & Polygonaceae & leaves & It is used to cure diarrhea. \\
\hline Pouzolzia zeylanica & Borali-bokua & Urticaceae & Whole plant & Whole plant paste is used for cut \\
\hline
\end{tabular}




\begin{tabular}{|c|c|c|c|c|}
\hline (L.) Benn. & & & & $\begin{array}{l}\text { and wounds. Juice of plant is } \\
\text { applied to cure boils. }\end{array}$ \\
\hline Psidium guajava $\mathrm{L}$. & Modhuri & Myrtaceae & $\begin{array}{l}\text { Leaves and } \\
\text { Fruit }\end{array}$ & $\begin{array}{l}\text { The extract of leaves is used to } \\
\text { cure dysentery. Ripe fruit is edible. }\end{array}$ \\
\hline $\begin{array}{l}\text { Pteridium aquilinum } \\
\text { (L.) Kuhn }\end{array}$ & Bihlongoni & Polypodiaceae & Leaves & $\begin{array}{l}\text { Leaves are used to cure urine } \\
\text { problem. }\end{array}$ \\
\hline Raphanus sativus L. & Mula & Brassicaceae & Whole plant & $\begin{array}{l}\text { It is used as vegetables to cure } \\
\text { kidney stone }\end{array}$ \\
\hline $\begin{array}{l}\text { Rhynchostylis retusa } \\
\text { Blume }\end{array}$ & Kopou-phul & Orchidaceae & $\begin{array}{l}\text { Root and } \\
\text { Leaf }\end{array}$ & $\begin{array}{l}\text { Aerial root paste is used to ear } \\
\text { ache. Leaf paste is used against } \\
\text { rheumatism. }\end{array}$ \\
\hline Ricinus communis L. & Era gos & Euphorbiaceae & Leaves & $\begin{array}{l}\text { Paste of leaves is used in muscular } \\
\text { pain and joint pain. }\end{array}$ \\
\hline $\begin{array}{l}\text { Rubus alceifolius } \\
\text { Poir. }\end{array}$ & Jejelipoka & Rosaceae & $\begin{array}{l}\text { Leaves and } \\
\text { Fruits }\end{array}$ & $\begin{array}{l}\text { Leaves are used to cure gastric } \\
\text { ulcer. Fruits are used against } \\
\text { mouth ulcer. }\end{array}$ \\
\hline $\begin{array}{l}\text { Saccharum } \\
\text { officinarum } \mathrm{L} .\end{array}$ & Kuhiar & Poaceae & Stem & $\begin{array}{l}\text { Stem juice is used to cure } \\
\text { jaundice. It is used to cure urine } \\
\text { problem. }\end{array}$ \\
\hline $\begin{array}{l}\text { Sapindus mukorossi } \\
\text { Gaertn. }\end{array}$ & Manisaal & Sapindaceae & Seed & $\begin{array}{l}\text { Seed is used to cure tonsillitis also } \\
\text { used as detergent. }\end{array}$ \\
\hline Saraca asoca (Roxb.) & Ashok phul & Fabaceae & Bark & $\begin{array}{l}\text { Bark is used to cure menstruation } \\
\text { problem. }\end{array}$ \\
\hline Scoparia dulcis $\mathrm{L}$. & Seni-bon & Scrophulariaceae & Leaves & $\begin{array}{l}\text { Leaves decoction are used to cure } \\
\text { cough and diabetes. }\end{array}$ \\
\hline Sesamum orientale $\mathrm{L}$. & Til & Pedaliaceae & Seed & $\begin{array}{l}\text { The paste of seeds are used in hair } \\
\text { for dandruff. Seeds are edible. }\end{array}$ \\
\hline $\begin{array}{l}\text { Sesbania grandiflora } \\
\text { (L.) Pers. }\end{array}$ & Augastia & Fabaceae & Root & $\begin{array}{l}\text { Root part is used as medicine for } \\
\text { Jaundice. }\end{array}$ \\
\hline $\begin{array}{l}\text { Smilax } \quad \text { perfoliata } \\
\text { Lour. }\end{array}$ & Tikonibarua & Smilacaceae & $\begin{array}{l}\text { Root } \\
\text { Shoot }\end{array}$ & $\begin{array}{l}\text { Root is used to cure Mental } \\
\text { disorder. Young shoot is also used } \\
\text { as vegetable. }\end{array}$ \\
\hline $\begin{array}{l}\text { Solanum anguivi } \\
\text { Lamk. }\end{array}$ & Titabhekuri & Solanaceae & Fruit & $\begin{array}{l}\text { It is used for purifying blood. It is } \\
\text { used to cure cough and stomach } \\
\text { ache. }\end{array}$ \\
\hline Solanum nigrum L. & Latkochi & Solanaceae & Leaves & $\begin{array}{l}\text { It is used as vegetable. It is used to } \\
\text { cure dysentery. }\end{array}$ \\
\hline $\begin{array}{l}\text { Spondias } \\
\text { (L.f.) Kurz }\end{array}$ & Amora & Anacardiaceae & $\begin{array}{ll}\text { Fruit } & \text { and } \\
\text { Leaves }\end{array}$ & $\begin{array}{l}\text { Fruit is used in dysentery. Leaf } \\
\text { paste is applied against small pox. }\end{array}$ \\
\hline $\begin{array}{l}\text { Syzygium jambos (L.) } \\
\text { Alston. }\end{array}$ & Воgајати & Myrtaceae & $\begin{array}{l}\text { Bark and } \\
\text { Fruit }\end{array}$ & $\begin{array}{l}\text { Bark is used to cure dysentery. } \\
\text { Ripe fruit is edible. }\end{array}$ \\
\hline $\begin{array}{l}\text { Syzygium cumini (L.) } \\
\text { Skeels }\end{array}$ & Kulajamu & Myrtaceae & Fruit & Used for cure diabetes. \\
\hline $\begin{array}{l}\text { Tabernaemontana } \\
\text { divaricata G.Don }\end{array}$ & Kutoni & Apocynaceae & $\begin{array}{l}\text { Flower and } \\
\text { Root }\end{array}$ & $\begin{array}{l}\text { Flower paste is used to cure eye } \\
\text { diseases. Root paste is used to cure } \\
\text { Malaria. }\end{array}$ \\
\hline Tagetes patula $\mathrm{L}$. & Narjiful & Asteraceae & Leaves & $\begin{array}{l}\text { Leaf paste is used in wounds for } \\
\text { stop bleeding. }\end{array}$ \\
\hline Tamarindus indica $\mathrm{L}$. & Teteli & Caesalpiniaceae & Fruit & $\begin{array}{l}\text { Fruit is eaten to cure high blood } \\
\text { pressure and dried fruit is used } \\
\text { against dysentery. }\end{array}$ \\
\hline $\begin{array}{lr}\text { Terminalia } & \text { arjuna } \\
\text { (Roxb. Ex } & \text { DC.) } \\
\text { Wight \& Arn. } & \\
\end{array}$ & Arjun & Combretaceae & Bark & $\begin{array}{l}\text { Juice is used as tonic and ailment } \\
\text { of Cancer disease. }\end{array}$ \\
\hline Terminalia bellirica & Bhomora & Combretaceae & Seed & Seed is used to cure urine disease \\
\hline
\end{tabular}




\begin{tabular}{|l|l|l|l|l|}
\hline (Gaertn.) Roxb. & & & & and jaundice. \\
\hline $\begin{array}{l}\text { Terminalia chebula } \\
\text { Retz. }\end{array}$ & Hilikha & Combretaceae & Fruit & $\begin{array}{l}\text { Fruit is useful in medicine for } \\
\text { diarrhea and dysentery. }\end{array}$ \\
\hline $\begin{array}{l}\text { Vitex negundo L. } \\
\text { Posotia }\end{array}$ & Verbenaceae & Leaves & $\begin{array}{l}\text { It is used for dysentery and leaf } \\
\text { paste used externally to cure } \\
\text { body pain. }\end{array}$ \\
\hline $\begin{array}{l}\text { Xanthium indicum } \\
\text { J.Koenig ex Roxb. }\end{array}$ & Agerua & Asteraceae & Fruit & $\begin{array}{l}\text { Fruits are used for preventing pain } \\
\text { from tooth. }\end{array}$ \\
\hline $\begin{array}{l}\text { Zanthoxylum nitidum } \\
\text { Bunge }\end{array}$ & Tejmuri & Rutaceae & $\begin{array}{l}\text { Leaves, Root } \\
\text { and Bark }\end{array}$ & $\begin{array}{l}\text { Leaves are used medicinally for } \\
\text { fever, cough and diarrhea. Bark is } \\
\text { used against tooth pain. Root is } \\
\text { used to cure asthma. }\end{array}$ \\
\hline $\begin{array}{l}\text { Zingiber officinale } \\
\text { Roscoe }\end{array}$ & Ada & Zingiberaceae & Rhizome & $\begin{array}{l}\text { Fresh rhizome is used to cure } \\
\text { cough and headache. }\end{array}$ \\
\hline Ziziphus jujuba Lam. & Bogori & Rhamnaceae & $\begin{array}{l}\text { Fruit and } \\
\text { Root }\end{array}$ & $\begin{array}{l}\text { Ripe fruit is used for gastric } \\
\text { disorder and it is edible. Root juice } \\
\text { is used to cure diarrhea. }\end{array}$ \\
\hline
\end{tabular}

\section{Results And Discussion:-}

In the present study a total of 142 plants belonging to 63 families were reported which were commonly used by Mising traditional healers for the treatment of 48 types of ailments (Table 1). The prominent family was Euphorbiaceae with 7 species, followed by Solanaceae and Asteraceae with 6 species, Lamiaceae, Poaceae, Rutacaea and Zingiberaceae with 5 species, Acanthaceae, Araceae, Amaranthaceae, Apocynaceae, Caesalpiniaceae, Fabaceae and Malvaceae with 4 species respectively (Fig 3).

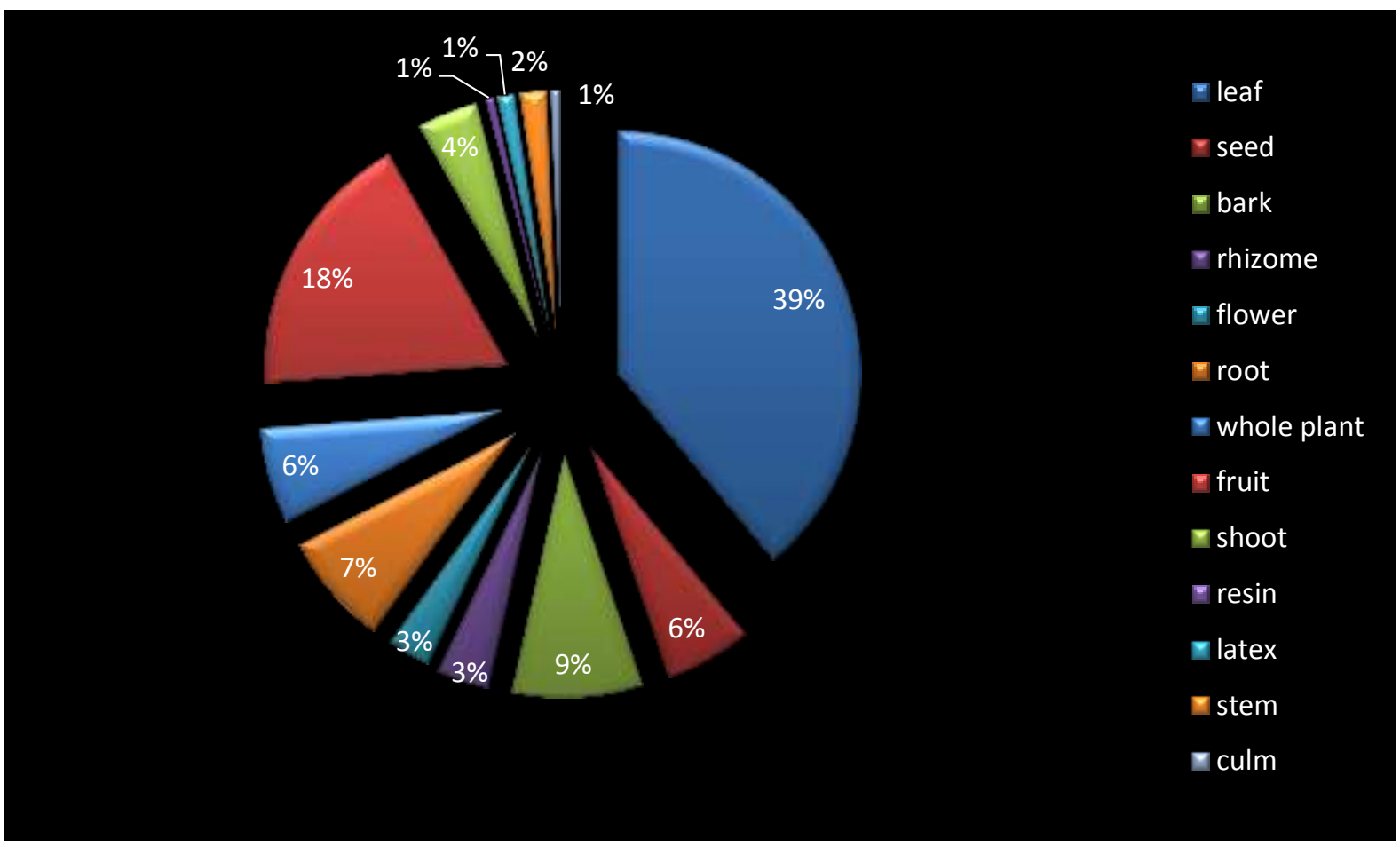

Fig 2:- Diversity of Plants Parts Used. 


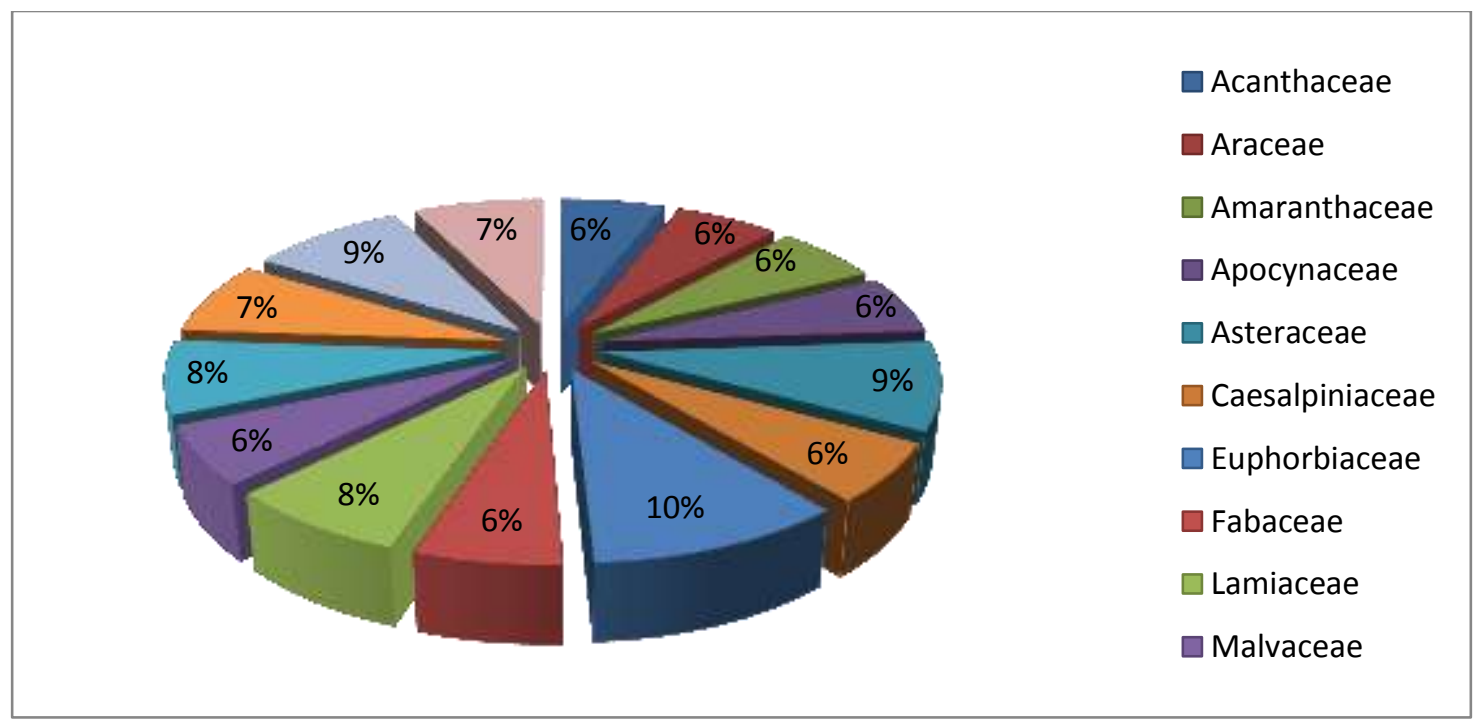

Fig 3:- percentage of dominant families documented from the study area.

Of the total 142 plant parts used as medicine, leaf is used majority of cases with 67 (39\%) species. It was followed by fruit $31(18 \%)$, bark $15(9 \%)$, root 13(7\%), whole plant $11(6 \%)$, seed $10(6 \%)$, shoot $7(4 \%)$, rhizome and flower 6 and 5 respectively (3\%), stem $3(2 \%)$, latex $2(1 \%)$ and resin and culm $1(1 \%)$ each species. Leaves were used mostly because leaves are available and collected very easily than underground parts, flowers and fruits etc. (Fig 2). Majority of the plants are used in Dysentery with 25 species, Cough with 19 species, Diarrhea with 13 species, Urine problem with 10 species, Jaundice with 9 species, Pneumonia and Cut and Wounds with 8 species each etc. Remaining plants are used in the treatment of Tonsillitis, Tooth pain, Malaria, Lactation problem, Uvulitis, Piles, Small pox, Ringworm, Cancer etc. (Table 1). Present investigation indicates the high diversity of plants used for medicinal purpose to cure their day to day ailments.

\section{Acknowledgement:-}

The author is thankful to the local herbal practitioners and villagers for co-operating with the survey by sharing their valuable ethnomedicinal knowledge.

\section{References:-}

1. Bor, N.L. (1940). Flora of Assam. Vol. 5 (Graminaceae). Govt. of Assam, Shilong.

2. Borthakur, S.K. (1976). Less known medicinal plants among the tribes of Karbi-Anglong (Mikir hills), Assam. Bulletin Botanical Survey India. Vol.: 18(1-4). Pp. 166-171.

3. Das, A.K., Dutt, B.K., Sharma, G.D. and Hajra, P.K. (2010). Medicinal plants of Southern Assam, Deep publication.

4. Jain, S.K. \& Rao, R.R. (1977). Handbook of Field and Herbarium Methods. New Delhi.

5. Kanjilal, U.N. Kanjilal, P.C. Das, A. and Purkayastha, C. (1934-1940). Flora of Assam, vol. 1-4. Govt. of Assam, Shillong.

6. Kattamani, K.N. Munikrishnappa, B.M., Hussain, S.A. and Reddy, P.N. (2000). Uses of plants as medicine under semi arid of tropical climate of Raipur district of North Karnataka. Journal of Medicinal Arom. Plant science 22.23: 406-410.

7. Namsa, N.D., Tag, H., Mandal, M. and Das, A.K. (2009). An ethnobotanical study of traditional anti-inflammatory plants used by the Lohit community of Arunachal Pradesh, India, Journal of Ethnopharmacology. Vol.: 125(2). Pp. 234-245.

8. Pei, S.I. (2001). Ethnobotanical approaches of traditional medicine studies: some experiences from Asia. Pharm. Biol. 39. Pp. 74-79.

9. Sajem, A.L. and Gosai, K. (2006). Traditional use of medicinal plants by the Jayantia tribes in North Cacar Hills district of Assam, northeast India, Journal of Ethnobiology and Ethnomedicine. 1746-4269.

10. Sharma, B.D., Balakrishnanah, N.P., Rao, R.R. and Hajra, P.K. (Eds.) 1993. Flora of India, vol. 1 (Ranunculaceae Barclayaceae). B.S.I., Calcutta.

11. Shrestha, P.M. (2003). Medicinal plant diversity and use in the highlands of Dolakha district, Nepal, Journal of Ethnopharmacology. Vol.: 86 (1). Pp. 81-96.

12. URL http://en. Wikipedia, Demography of Dhemaji, html. 